\title{
Adoption of Rain Water Harvesting Structures in Dry Land Areas of Tamil Nadu, India
}

\author{
A. Anitha Pauline ${ }^{*}$, K. Mahandrakumar and C. Karthikeyan \\ Department of Agricultural Extension and Rural Sociology, AC \& RI, Madurai, India \\ *Corresponding author
}

\begin{tabular}{l} 
K e y w o r d s \\
Water harvesting \\
structures, \\
Hydrologic \\
Simulation, \\
GIS and HEC-Geo- \\
HMS Model \\
Article Info \\
$\begin{array}{l}\text { Accepted: } \\
\text { 28 February } 2020 \\
\text { Available Online: } \\
\text { 10 March } 2020\end{array}$ \\
\hline
\end{tabular}

Water is an essential commodity for survival and development. But the ever- increasing human population, technological, modernization, changing life patterns and erratic monsoons are likely to lead to water crisis in this millennium. One of the solutions that can be implemented quickly is Water Harvesting. It can be defined as the collection and storage of rainwater for later productive use. The study mainly focused on the water harvesting structures adopted by farmers in dry land areas of Tamil Nadu. The study was conducted in four districts of Tamil Nadu such as Virudhunagar, Ramanathapuram, Sivagangai and Madurai based on the maximum area under dry lands condition. In these locale, the villages were selected by appraisal of several indicators namely rainfall, climate conditions, livelihood analysis and overall agriculture development. Participatory Rural Appraisal methodology was adopted to identify and gather information about the water harvesting practices for water saving. Key informants including progressive farmers belonging to small, marginal and big farmer categories, aged farmers, farm women \& farm labourers were involved during the process of data collection. Documentation of water harvesting practices was done using both primary and secondary sources of information. In-depth study was designed by combining descriptive survey and anthropological approach of participatory study. The villagers had developed different water storage techniques/ structures in such a way so that the groundwater as well as rainwater could be utilized properly. Various water conservation techniques/ structures found in the dry land area of Tamil Nadu are farm ponds, tank irrigation system; compartmental bunding and recharge pit etc have been described.

\section{Introduction}

Water harvesting is the activity of direct collection of rainwater, which can be stored for direct use or can be recharged into the groundwater. Each state of India has its own water harvesting structures reflecting geographical peculiarities and cultural uniqueness of the community. The residents of different states in India have developed their own indigenous water harvesting techniques to meet their water requirements. There were many water harvesting structures prevalent in Tamil Nadu since ancient times. Water Harvesting primarily aims at collecting and storing any form of water rainfall, runoff 
or sub-surface flow to meet the increased water demand and tide over moisture stress conditions. Water Harvesting structures are site specific and designed to fulfil multiple objectives in a watershed such as Irrigation purpose, domestic uses, drinking water for livestock and ground water recharge.

History tells us that both floods and droughts were regular occurrence in ancient India. Perhaps this is why every region in the country has its own water harvesting techniques that reflect the geographical peculiarities and cultural uniqueness of the regions. The basic concept underlying all these techniques is that rain should be harvested whenever and wherever it falls. Therefore on farm water conservation and storage practices (Vohland and Barry, 2010) at low cost are to be adopted depending on the local climatic conditions (Palmier et al., 2010). This study mainly focused on documentation of water harvesting structures in dry lands and their importance in the locality.

\section{Materials and Methods}

The study was conducted to find out the water harvesting structures adopted by farmers in dry land areas of Tamil Nadu. Virudhunagar, Ramanathapuram, Sivagangai and Madurai districts were selected for documenting the water harvesting structures based on the maximum area under dry lands condition. In these locale, the villages were selected by appraisal of several indicators namely rainfall, climate conditions, livelihood analysis and overall agriculture development.

Participatory Rural Appraisal methodology was adopted to identify and gather information about the water harvesting practices for water saving. Key informants including progressive farmers belonging to small, marginal and big farmer categories, aged farmers, farm women \& farm labourers were involved during the process of data collection. Documentation of ITK was done using both primary and secondary sources of information. By contacting the respondents through one to one interaction and group discussion methods, the water harvesting structures used by dry land farmers were documented. Triangulation exercise was also done in the study villages to gather reliable information about water harvesting structures. In-depth study was designed by combining descriptive survey and anthropological approach of participatory study. For selection of sample for the study, multi stages of quota sampling method were employed, starting from selection of districts, blocks, villages and respondents. Totally 320 respondents were selected for the study.

Table.1 Selection of study area

\begin{tabular}{|c|c|c|c|}
\hline S.No. & District & Selected Blocks & Number of respondents \\
\hline $\mathbf{1 .}$ & Madurai & Thirumangalam & 80 \\
\hline $\mathbf{2 .}$ & Virudunagar & Kariapatti & 80 \\
\hline $\mathbf{3 .}$ & Sivagangai & Illayankudi & 80 \\
\hline $\mathbf{4 .}$ & Ramanathapuram & Paramakudi & 80 \\
\hline & Total & $\mathbf{4}$ & $\mathbf{3 2 0}$ \\
\hline
\end{tabular}

This table provides details of major adopted water harvesting structures in the study areas. 
Table.2 Major water harvesting structures in the study area

\begin{tabular}{|c|c|c|c|c|c|}
\hline $\begin{array}{c}\text { Rain Water } \\
\text { Harvesting Structures }\end{array}$ & $\begin{array}{c}\text { Rainfall } \\
(\mathbf{m m})\end{array}$ & $\begin{array}{c}\text { Slope } \\
(\mathbf{\%})\end{array}$ & Soil Type & $\begin{array}{c}\text { Land use/ } \\
\text { cover }\end{array}$ & $\begin{array}{c}\text { Catchment } \\
\text { area (ha) }\end{array}$ \\
\hline Farm pond & $>200$ & $<5$ & $\begin{array}{c}\text { Sandy clay } \\
\text { loam/silty } \\
\text { loam }\end{array}$ & $\begin{array}{c}\text { moderately } \\
\text { cultivated } / \\
\text { shrub land }\end{array}$ & $<2$ \\
\hline Check dams & $<1000$ & $<15$ & $\begin{array}{c}\text { Sandy clay } \\
\text { loam }\end{array}$ & $\begin{array}{c}\text { Barren/ shrub } \\
\text { land }\end{array}$ & $>25$ \\
\hline Percolation pond & $<1000$ & $<10$ & $\begin{array}{c}\text { Silt loam/ } \\
\text { clay loam }\end{array}$ & $\begin{array}{c}\text { Barren/ shrub } \\
\text { land }\end{array}$ & $>25$ \\
\hline Tank & $<1000$ & $<10$ & Silt loam & $\begin{array}{c}\text { Barren/ shrub } \\
\text { land }\end{array}$ & $>40$ \\
\hline
\end{tabular}

\section{Results and Discussion}

Water harvesting is a technique by which the water can be collected either surface or subsurface to store up during wet period and used during dry period by applying a proper technique such as channel reservoir, on-farm reservoir, infiltration ditches, infiltration well, check dams, water harvesting dike etc. The water harvesting is addressed and very significance for several objectives including (a) increase recharge groundwater, (b) increase base flow, (c) reduce peak runoff, (d) reduce the risk of flood in downstream areas, (e) extend the time response to runoff generation, and (f) increase available water for irrigation and other uses (domestic, industry, municipal, etc).

This paper provides detail about adoption of water harvesting structures in dry land areas of Tamil Nadu by the farmers. This paper is divided into two sections viz., water harvesting structures at domestic/ individual farm level and Community/ village level.

\section{List of water Harvesting Structures at individual farm level}

The study was conducted in four districts of Tamil Nadu. Nearly 6 rain water harvesting structures were identified in the study area other than dug wells/ open wells and bore wells. The details are given below in Table 3 .

\section{Compartmental Bunding}

Bunding is a very effective soil and water conservation measure especially in dry areas. Compartmental bunds, also called as Peripheral or field bunds are small earthern bunds constructed along field boundaries without consideration of contour. Compartmental bunding is more beneficial in medium to deep black soils with high clay content $(>45 \%)$ and low infiltration rate $(0.8$ to $1.2 \mathrm{~mm} \mathrm{~h}-1)$. Farmers in the study area reported that adoption of compartmental bunding reduces runoff and nutrient losses. It is a low cost in situ moisture conservation practice that can be easily laid out with the help of a bund former in the farmers' fields.

\section{Land levelling/shaping}

Land levelling reshapes or modifies the land surface to a planned grade or slope, so as to control the runoff, check the soil erosion and conserve the moisture for better growth. Bunding and levelling have extensively demonstrated beneficial results in drought prone areas the convert the slopped fallow/undulated fallow to cultivable lands. Cent per cent of the respondents were adopted 
that levelling to maintain the moisture content in the soil.

\section{Deep Ploughing}

This refers to mechanized deep ploughing technology. Through deep ploughing by machines, we can break the sub-arable layer without disturbing surface soil layer so as to improve soil ventilation and rainfall retention capacity.

\section{Trench cum bund}

In this method the trenches or pits are dug out across the slope and along the contour, suitable to the vegetation/crop present in the area. These structure store runoff water as well eroded soil by reducing the runoff velocity and providing more time for its percolation.

\section{Farm Ponds}

The collection of rainwater and storing in big ponds in the farm itself is the basic concept of Farm pond. Farm ponds are small storage structures constructed at the lowest point of a farm to collect and store run-off water. The water harvested through farm pond can be used for protective irrigation to crops at critical stages. Apart from that, stored water can be used as drinking water for cattle and other domestic usages. Farm ponds can recharge the ground water and the adjacent wells in the region.

Farm Ponds can also be used as a Fish Pond which would serve as an additional source of income for the farmers. Farm Pond may be square or rectangular in shape based on the dimensions and area of the field. Generally, the recommended size of the Farm Pond is $30 \mathrm{mx} 30 \mathrm{~m}$ with the depth varying from $1.20 \mathrm{~m}$ to $2.00 \mathrm{~m}$ depending on the available soil depth. Pipes or masonry structures may be provided as inlet and outlet arrangements with proper silt traps in the upstream portion of the inlet. Water conservation by farm pond and open well with recharging structures helped in creating additional source for sub-soil water for production purpose.

Agriculture Engineering Department, District Watershed Development Agency, District Rural Development Agency \& NGOs (201718).

\section{Recharge pit}

In block soil area, during the rainy seasons, the tanks and water harvesting structures will be fully filled up but water from these structures does not percolate into Ground Water table. This is suitable where impervious layer is encountered at shallow depth. The normal diameter of shaft should be more than $2 \mathrm{~m}$ to accommodate more water.

A silt free source water can be put into recharge pit directly through pipes. In case of silty water, it is suitably filtered through coarse sand passage before recharging. These structures are cost effective, less evaporative, and require less land area.

\section{Adoption of water harvesting structures in the study}

From the Table 5, it is concluded that cent percent of the respondents adopted land leveling followed by deep ploughing $(92.50 \%)$. Nearly three- fourth of the respondents had adopted farm pond in their farm and compartmental bunding (72.50\%). Less than half of the respondents adopted trench cum bund $(42.18 \%)$ and recharge pit $(39.00 \%)$. It is clearly seen that, farmers in the study area had adopted more than one water harvesting structure in their farm to store rain water. 


\section{List of water Harvesting Structures at Community/ village level}

This part provides details about common water harvesting structures available in the study area. Nearly 6 WHS have been identified and details are given in Table 6 .

\section{Percolation Ponds}

This is the most common method for artificial recharge. Percolation Ponds are small storage structures constructed across natural streams and nallas to collect, spread and impound surface runoff to facilitate infiltration and percolation of water into the sub-soil for augmenting ground water recharge.

The ponds may be designed to store about one-third of the annual yield from the catchment and 1.5 to 2 fillings of the monsoon runoff are assumed. During the field visit, farmers in the study area expressed wells water increased 1-2 $\mathrm{m}$ due to constriction of percolation ponds in their locality. This water utilized for irrigating the wet crops.

\section{Recharge Shaft}

In case, poorly permeable strata overlie the water table aquifer located deep below land surface, a shaft is used for causing artificial recharge. A recharge shaft is similar to a recharge pit but much smaller in crosssection. Hence, recharge shafts are used in shallow aquifer to recharge the ground water table within the existing water bodies / water harvesting structures. It Conserved and stored of excess surface water for future requirements. It improves the quality of existing groundwater through dilution.

\section{Check Dam}

Check dams are constructed across a water course (eg. nala, stream) to create a water reservoir. It is called impervious / impermeable because it does not allow water to permeate to the other side. The water impounded in these structures help to retain the moisture in the area of longer periods. The dam can be constructed of selected earth that is properly compacted, solid masonry, plain cement concrete, RCC, stone / RCC slabs, etc.,

\section{Tank Irrigation (Eri)}

Tanks are part of an ancient tradition of harvesting and preserving the local rainfall and water from streams and rivers for later use, primarily for agriculture and drinking water, and for sacred bathing and ritual.

Tank irrigation is one of the oldest and significant sources of irrigation in India and is particularly in south India (Palanisamy, 1998). Irrigation tanks accounted for more than one third of the area irrigated in the south Indian states on Tamil Nadu, Karnataka and Andhra Pradesh. The tanks occupy vital role in the irrigation as well as local ecosystem in the semiarid and regions of South India. This tank provides multiple uses like source of drinking water for uncountable rural and urban communities and livestock, fish culture, recharge of ground water, control of floods etc (Gurunathan, 2006). Tanks have many positive attributes such as less capital intensive to build and maintain, provide ecological benefits, recharging ground water, control the floods and provided livelihood options such as farming, fishing, and forestry and dug hearing (Sivasubramaniyan, 2006). 
Table.3 List of water Harvesting Structures at individual farm level

\begin{tabular}{|c|c|c|c|c|c|c|}
\hline S.No & Name & $\begin{array}{l}\text { Local } \\
\text { Name }\end{array}$ & Cost & Size & Benefits & Durability \\
\hline 1. & $\begin{array}{l}\text { Compartmental } \\
\text { Bunding } \\
\text { (Embankment of } \\
\text { earth) } \\
\text { Peripheral or } \\
\text { field bunds are } \\
\text { small earthern } \\
\text { bunds }\end{array}$ & $\begin{array}{l}\text { "Varapu" } \\
\text { or Kattu } \\
\text { patthi } \\
\text { murai" }\end{array}$ & $\begin{array}{l}\text { Rs. } 3000 / \\
\text { ha }\end{array}$ & $\begin{array}{l}\text { Depends upon } \\
\text { field size. } \\
\text { Adopted up to } 8 \% \\
\text { slope }\end{array}$ & $\begin{array}{l}\text { 1.Reduce the velocity } \\
\text { of runoff } \\
\text { 2.Control soil erosion } \\
\text { 3.Improve the soil } \\
\text { moisture regime }\end{array}$ & $1-3$ years \\
\hline 2. & $\begin{array}{l}\text { Land leveling } \\
\text { (reshapes or } \\
\text { modifies the land } \\
\text { surface) }\end{array}$ & & $\begin{array}{l}\text { Rs.1500/ } \\
\text { ha }\end{array}$ & $\begin{array}{l}\text { Depends } \\
\text { field size. }\end{array}$ & $\begin{array}{l}\text { convert the slopped } \\
\text { fallow/ undulated } \\
\text { fallow to cultivable } \\
\text { lands }\end{array}$ & $\begin{array}{l}3-6 \\
\text { months }\end{array}$ \\
\hline 3. & $\begin{array}{l}\text { Deep Ploughing } \\
\text { / Summer } \\
\text { Ploughing }\end{array}$ & $\begin{array}{l}\text { "Kodai } \\
\text { Uzavu" }\end{array}$ & $\begin{array}{l}\text { Rs.3000/ } \\
\text { ha }\end{array}$ & $\begin{array}{l}\text { Depends } \\
\text { farm size }\end{array}$ & $\begin{array}{l}\text { 1.To break the hard } \\
\text { soil pan } \\
\text { 2.Facilitate aeration } \\
\text { and absorption of } \\
\text { rainwater }\end{array}$ & 3 Months \\
\hline 4. & Trench cum bund & $\begin{array}{l}\text { "Kuli } \\
\text { Varappu" }\end{array}$ & $\begin{array}{l}\text { Rs.5000/ha } \\
\text { 1cubic } \\
\text { metre - } \\
\text { Rs.40 }\end{array}$ & $\begin{array}{l}\text { Length: } 2 \mathrm{~m} \\
\text { Width : } 0.6 \mathrm{~m} \\
\text { Depth : } 0.5-1 \mathrm{~m}\end{array}$ & $\begin{array}{l}\text { 1.To store water in } \\
\text { the field it self } \\
2 . \text { To conserve } \\
\text { moisture in the field }\end{array}$ & 3 Years \\
\hline 5. & Farm pond & $\begin{array}{l}\text { "Pannai } \\
\text { Kuttai" }\end{array}$ & $\begin{array}{l}\text { Rs. 20000- } \\
50000 / \\
\text { pond }\end{array}$ & $\begin{array}{l}30 \mathrm{~m} * 30 \mathrm{~m} * 1.5 \mathrm{~m} \\
\text { Capacity of the } \\
\text { pond : } 0.040 \mathrm{mcft}\end{array}$ & $\begin{array}{l}\text { 1.Recharge the } \\
\text { ground water and } \\
\text { adjacent well } \\
\text { 2.Serve as fish pond }\end{array}$ & 10 years \\
\hline 6. & Recharge pit & Pit & $\begin{array}{l}\text { Rs. } 4000- \\
5000 / \text { pit }\end{array}$ & $\begin{array}{l}\text { Length : } 2 \mathrm{~m} \\
\text { Width: } 2 \mathrm{~m} \\
\text { Depth: } 1 \mathrm{~m}\end{array}$ & $\begin{array}{l}\text { 1.Recharge } \\
\text { ground water and } \\
\text { adjacent well }\end{array}$ & 5 Years \\
\hline
\end{tabular}

Table.4 Number of farm ponds in the study area

\begin{tabular}{|c|c|c|}
\hline S.No. & District & Total number of farm ponds \\
\hline $\mathbf{1 .}$ & Madurai & 740 \\
\hline $\mathbf{2 .}$ & Virudunagar & 915 \\
\hline $\mathbf{3 .}$ & Sivagangai & 2500 \\
\hline $\mathbf{4 .}$ & Ramanathapuram & 5210 \\
\hline & Total & $\mathbf{9 3 6 5}$ \\
\hline
\end{tabular}

Agriculture Engineering Department, District Watershed Development Agency, District Rural Development Agency \& NGOs (2017-18) 
Table.5 Number of Farmers adopted water Harvesting Structures at farm level

\begin{tabular}{|c|c|c|c|}
\hline S.No & $\begin{array}{c}\text { Water Harvesting } \\
\text { structures }\end{array}$ & $\begin{array}{c}\text { Number of farmers adopted WHS } \\
\text { Compartmental } \\
\text { Bunding }\end{array}$ & $\begin{array}{c}\text { Percentage of farmers } \\
\text { adopted WHS }\end{array}$ \\
\hline $\mathbf{1 .}$ & 232 & 72.50 \\
\hline $\mathbf{2 .}$ & Land leveling & 320 & 100.00 \\
\hline $\mathbf{3 .}$ & $\begin{array}{c}\text { Deep Ploughing / } \\
\text { Summer Ploughing }\end{array}$ & 295 & 92.50 \\
\hline $\mathbf{4 .}$ & Trench cum bund & 135 & 42.18 \\
\hline $\mathbf{5 .}$ & Farm pond & 240 & 75.00 \\
\hline $\mathbf{6 .}$ & Recharge pit & 125 & 39.00 \\
\hline
\end{tabular}

$\left({ }^{*}\right.$ Multiple response obtained $)$

Table.6 List of water Harvesting Structures at Community/ village level

\begin{tabular}{|c|c|c|c|c|c|c|}
\hline S.No & Name & Local Name & Cost & Size & Benefits & Durability \\
\hline 1. & $\begin{array}{l}\text { Percolation } \\
\text { ponds }\end{array}$ & $\begin{array}{l}\text { Kasivu neer } \\
\text { Kuttai }\end{array}$ & $\begin{array}{l}\text { Rs. 20000- } \\
30000\end{array}$ & Any size & $\begin{array}{l}\text { 1.Recharge the near Water } \\
\text { Harvesting structures }\end{array}$ & 5-7 Years \\
\hline 2. & $\begin{array}{l}\text { Recharge } \\
\text { shaft }\end{array}$ & & $\begin{array}{l}\text { Rs. } 4000 / \\
\text { Shaft }\end{array}$ & $\begin{array}{l}1-2 \mathrm{~m} \text { length/ } \\
\text { width }\end{array}$ & Recharge the well & 5 years \\
\hline 3. & Check dam & Thadupannai & $\begin{array}{l}\text { Rs. } 50,000 \\
\text { to } 1 \text { Lakhs }\end{array}$ & $\begin{array}{l}\text { Water holding } \\
\text { capacity is } 210 \\
\text { CuM. }(0.0075 \\
\text { Mcft }) \text {. }\end{array}$ & $\begin{array}{l}\text { 1. Run off Rain water is curbed. } \\
\text { 2. Top soil erosion on the } \\
\text { upstream side of the dam is } \\
\text { reduced. } \\
\text { 3. Widening of the gully course } \\
\text { is also restricted. } \\
\text { 4. Trapped silt is used as } \\
\text { manure. }\end{array}$ & 10-15 Years \\
\hline 4. & $\begin{array}{l}\text { Tank } \\
\text { irrigation }\end{array}$ & $\begin{array}{l}\text { Eri/ Kanmai/ } \\
\text { Thongal }\end{array}$ & $\begin{array}{l}\text { More than } \\
\text { one lakhs }\end{array}$ & Any size & $\begin{array}{l}\text { 1.preventing soil erosion and } \\
\text { wastage of runoff during } \\
\text { periods of heavy rainfall, and } \\
\text { recharging the groundwater in } \\
\text { the surrounding areas. }\end{array}$ & $\begin{array}{lr}20 \text { to } & \text { more } \\
\text { than } & 100 \\
\text { years } & \end{array}$ \\
\hline 5. & Village pond & $\begin{array}{l}\text { Oorani/ } \\
\text { Kanmai }\end{array}$ & Rs. 50,000 & $\begin{array}{l}\text { Any size } \\
40 \times 40 \times 1.50 \\
\text { meter. } \\
\text { Capacity of the } \\
\text { pond: } 0.085 \\
\text { mcft. }\end{array}$ & $\begin{array}{l}\text { 1. Drinking Water purpose for } \\
\text { Cattle is served. } \\
\text { 2.Ground water recharged and } \\
\text { water level in the near wells } \\
\text { increased. }\end{array}$ & $5-10$ years \\
\hline 6. & Cattle ponds & Kuttai & Rs. 50000 & $\begin{array}{l}\text { Size of pond: } \\
40 \times 40 \times 1.50 \\
\text { meter. } \\
\text { Capacity of the } \\
\text { pond: } 0.085 \\
\text { mcft. }\end{array}$ & $\begin{array}{l}\text { 1.Drinking Water purpose for } \\
\text { Cattle } \\
\text { 2. stored water is used for } \\
\text { supplementary irrigation. } \\
\text { 3. Ground water recharged } \\
\text { increased. }\end{array}$ & $7-10$ years \\
\hline
\end{tabular}


During the field survey it has also been noticed that the situation of the farmers were very miserable due to failure of monsoon. They are fully dependent on rainfall. So, in this situation the raindrops are considered as a god who helps them in their worse situation. Therefore, in order to ride out from these prevailing situations, proper steps must be taken in favor of rural people by the government of Tamil Nadu.

On the other hand, the traditional water harvesting systems such as tank irrigation, wells (filled with rubble and garbage) and ponds has declined due to improper maintenance and use. These can be maintained and re-used only through the proper maintenance and cleaning. In earlier times the above storage structures were the best method of rainwater collection which in turns maintains the level of underground water. Finally, it can be concluded that the water harvesting is the need of hour today to conserve the water and reduce the problem of water scarcity.

\section{Acknowledgement}

The authors are very much thankful to the DST- Department of Science and Technology, New Delhi in the scheme entitled "DSTWomen Scientist Scheme-B" for sponsoring to Conduct study on " Performance Evaluation of farm ponds in dry land areas of Tamil Nadu.

\section{References}

1.Gurunathan, A. Shanmugam, C.R, (2006), Customary Rights and their Relevance in ModernTank Management: Select Cases in Tamil Nadu, Paper prepared for the workshop entitled 'Water, Law and the Commons' organized in Delhi from 8 to 10 December 2006 by the International Environmental Law Research Centre (ILERC).

2.Palanisamy, K. and R. Balasubramaniyan (1998), Common Property and Private Prosperity: Tank vs. Private Wells in Tamil Nadu, Indian Journal of Agricultural Economics, vol.53, No.4, Oct - December.

3.Palmier R. L. and Nóbrega B.L.R. 2010. Challenges for upgrading rainfed agriculture using water harvesting techniques in the Brazilian semi-arid region. (In:) Proceedings of the International Conference on Arid and Semi-Arid development through Water Augmentation (ASADWA). Valparaíso, Chile, From 13 to 16 December 2010. Technical Document IHP-LAC No 31

4.Sivasubramaniyan 2006. Sustainable Development of small water Bodies in Tamil Nadu, Economic and Political Weekly, June 30.

5. Vohland, K. and Barry, B. 2010. A review of in situ rainwater harvesting (RWH) practices modifying landscape functions in African drylands. Agriculture, Ecosystems and Environment, 131: 119-127.

\section{How to cite this article:}

Anitha Pauline, A., K. Mahandrakumar and Karthikeyan, C. 2020. Adoption of Rain Water Harvesting Structures in Dry Land Areas of Tamil Nadu, India. Int.J.Curr.Microbiol.App.Sci. 9(03): 3271-3278. doi: https://doi.org/10.20546/ijcmas.2020.903.375 